\title{
Micro-International Unit per Liter
}

National Cancer Institute

\section{Source}

National Cancer Institute. Micro-International Unit per Liter. NCI Thesaurus. Code C124464.

A unit of concentration (biologic activity) equal to one micro-international unit of substance per liter of solution. 